\title{
POWERLESS PARTNERS: ONE BEGGAR TELLING ANOTHER WHERE TO FIND BREAD
}

\author{
Johannes Knoetze \\ Department of Theology, \\ NWU Mafikeng Campus \\ Johannes.Knoetze@nwu.ac.za
}

\section{ABSTRACT}

The relationship between the 'powerful' Dutch Reformed Church (DRC) and the many churches that were planted by the mission work of the DRC has always been and still is a very sensitive matter. This paper will take a historical look at the relationship over the last decade (2004-2014) between the Dutch Reformed Church in Botswana (DRCB) and the Dutch Reformed Church in South Africa, especially the Dutch Reformed Church in the Northern Cape (DRCNC). It was during this time that a paradigm shift started developing in the relationship. After some socio-economic changes and 'new' missiological reflection from the DRCNC on their own understanding of mission, the DRCNC took a definite decision to move away from a deed of agreement relation with the DRCB and work towards a partnership relation. After requests from the DRCB regarding theological education, the DRCNC decided to broaden its vision to the church in Botswana and not only the DRCB. This paper wants to look at the process of transformation of a power relation which involves learning, unlearning, relearning and new learning of the different contexts, as well as the understandings and realities of mission, ecclesiology, partnership, tradition, interdependence, theological education and leadership.

Key words: Dutch Reformed Church in Botswana; Dutch Reformed Church Northern Cape; mission; ecclesiology; partnership

\section{UNISA $\cong$}

Studia Historiae Ecclesiasticae Volume 41 | Number 1 | 2015 pp. $40-55$
DOI: http://dx.doi.org/10.17159/2412-4265/2015/v41n1a4 Print ISSN 1017-0499 | Online 2374-3689 (C) 2015. Studia Historiae Ecclesiasticae 


\section{Introduction}

This paper will take a historical look at the relationship over the last decade (20042014) between the Dutch Reformed Church in Botswana (DRCB) and the Dutch Reformed Church in South Africa (DRCSA), especially the Dutch Reformed Church in the Northern Cape (DRCNC). The first purpose of this paper is to acknowledge some mission practices or paradigm shifts that have taken place within the understanding of mission in the DRC. ${ }^{1}$ The second purpose of this paper is to try and answer the question whether it is proper and necessary to plan for ending a mission action. ${ }^{2}$

This paper is subject to the following limitations: the first limitation is that it can be viewed as an ethnographic study; this implies that the author is personally involved in, and in many instances 'responsible' for, the relationship ${ }^{3}$ and writes from his own experience and perspectives. The second limitation is that it is written from a DRCSA/NC perspective without consultation with the DRCB.

\section{The DRC's theological understanding of mission}

In discussing this relationship or partnership, it is important to put it within a theological and historical context. The DRCSA worked with the understanding of mission according to the threefold mission definition of Voetius (quoted in Kritzinger 2011), namely the conversion of 'gentiles', the planting of the church and the glory and manifestation of God's grace. ${ }^{4}$ Native Africans were viewed as gentiles who should be converted to Christianity. Many churches were planted by the DRCSA mission, both within and outside the borders of South Africa. ${ }^{5}$ The DRCSA was strongly influenced by the church-planting model of Venn and Anderson (Shenk 1981), known as the three selves: self-supporting, self-governing and self-propagating. 'A main goal of the theory was the gradual transfer of control of the mission work, as well as the evangelisation of the community, to the "native people" themselves, by way of elected church councils in the local churches. ${ }^{6}$ In this regard, the structures of the DRCSA, which in many instances now seem to be sociological and financial constraints to 'younger' churches, were transferred to the newly planted DRC churches all over Africa. Looking back from a missional understanding of the missio Dei, some questions must be asked about the churchplanting model of Venn and Anderson. If mission is understood as God's work, is it fair to determine the church by the three selves, especially with regard to finances? When is a church self-supporting; only when it can afford to pay a minister? Is it only then viewed as a church?

Taking a big leap, it is to be noted that the mission statement of the DRCSA General Synod of 2002 clearly indicated a new understanding of the calling of the church. The first statement confirms the calling of the DRCSA to preach the Word of God in southern Africa. In the second statement, the DRCSA commits herself to the continent of Africa, especially southern Africa, 'to work together towards 
resolutions for our society' ('om mee te werk aan oplossings vir ons samelewing'). ${ }^{7}$ The third statement focuses on church unity within the DRC family as well as the strengthening and expansion of ecumenical ties with all Christians. It is also at this synod that the concept of 'missional diaconate' was put at the centre of the church calling. This led to a later re-structuring of the commissions of the General Synod, which is formed according to the calling of the church rather than the functions. ${ }^{8}$

\section{Paradigm shifts}

Looking at the short historical overview of the establishment of the DRCB, it is clear that some paradigm shifts had taken place. According to Bosch (2012), ${ }^{9}$ a new paradigm grows by way of 'revolutions', when a few individuals start to perceive reality in ways that are qualitatively different from predecessors. 'No individual or group can "create" a new paradigm; rather, it ripens within the context of an extraordinary network of diverse social and scientific factors. ${ }^{10}$ Saayman (2007) gives an overview of the DRC Mission ('attempting "to write Afrikaner history into their DRC Christianity" ' $)^{11}$ by describing four waves. ${ }^{12}$ These four waves are linked to specific persons and events. The first wave (1779-1834) is linked to the ministry of H.R. van Lier and M.C. Vos. The second wave (1867-1939) is linked to Dr Andrew Murray and other pioneer foreign missionaries. The third wave (19541976) is linked to Dr Thomlinson and his famous report. The fourth wave occurred from 1990 onward and is linked to F.W. de Klerk. It will become clear in this paper how the relationship between the DRCSA and DRCB developed through and was influenced by social, political and economic factors.

Bosch $^{13}$ warns that in theology, one may have the revival of a former (sometimes forgotten) paradigm, as well as the complete disappearance of the 'old paradigm' (Bosch 2012). More important for this paper is that people are often committed to more than one paradigm at the same time. Our paradigms are influenced by our theologies, which are only partial; therefore, a "theological approach is a "map" and that map is never the actual "territory".${ }^{14}$ The relationship between the DRCB and the DRCSA, and later the DRCNC, went through different theological approaches which had an influence on the relationship and also contributed to the fact that this relationship is often committed to more than one paradigm.

According to Martin (quoted in Bosch 2012), the history of the relationship of the churches and their theology can be divided into three eras: the first era is 'pre-critical' and 'symbolic'. The second era is the Enlightenment, characterised as 'critical', 'analytic' and 'mechanistic'. The third emerging era is described as 'postcritical', 'holistic' and 'ecumenical'. ${ }^{15}$ After the relationship of the DRCSA and the DRCB has gone through the first two eras, it is believed that currently, it finds itself in the third era. 
This paper will follow the history of the church in Botswana along the four waves of Saayman (2007) that were mentioned previously, since they may indicate new paradigms developing within the DRC's understanding of mission.

\section{First wave: 1779-1834. The beginning}

Church denominations in Botswana are mainly linked to the different tribes, since tribal authorities have adopted missionaries 'so that each tribal group has its own "mission" or brand of Christianity'. ${ }^{16}$ In general, the story of Christianity in Botswana begins in 1824 with a visit from Robert Moffat (from the London Missionary Society - LMS) of Kuruman to the Bangwaketse tribe. The first mission station was set up in 1846 amongst the Bakwena people in Kolobeng by David Livingstone and his bride, Mary Moffat. In 1851, the effects of a severe drought and a raid by the Boers sent Livingstone on his first of several expeditions. ${ }^{17}$ The London Missionary Society was adopted by three of the largest tribes, namely the Bangwaketse, the Bakwena and the Banwato, and is up to date one of the dominant denominations in Botswana.

\section{Second wave: 1867-1939. Crossing borders}

This paper focuses on the Bakgatla people, since the Dutch Reformed Church in Botswana (DRCB) is mainly found amongst them. In 1863 the Cape Synod of the Dutch Reformed Church sent the Swiss missionary, Henri Gonin, to work among the Bakgatla ba ga Kgafela tribe in the area of Saulspoort, near Rustenburg in South Africa. In 1870, under the leadership of Chief Kgamanyane, part of the Bakgatla people moved from the Pilanesberg to Mochudi in Bechuanaland. In 1874, chief Kgamanyane died and his eldest son, Lentswe, became chief.

According to Crafford (1982), ${ }^{18}$ two important Botswana tribes are the Bakwena and the Bamangwato, who were ministered to by the London Missionary Society (LMS) since 1846. Between 1884 and 1885, a growing interest by the British in 'Bechuanaland' led to the declaration of it as part of a British Protectorate. In 1895, Britain considered incorporating Bechuanaland into the British South African Company. Sebele, the then chief of the Bakwena, and Kgama, son of chief Sekgoma of Bamangwato, went to England in 1895 to complain about this possible incorporation and it was consequently stopped. The British High Commissioner was appointed as the governor of Bechuanaland. This was almost a textbook example of 'indirect rule', since the Resident Commissioner lived in Mafikeng, South Africa, and Botswana was governed by the tribal chiefs and customs. ${ }^{19}$ Between 1875 and 1880, there were tribal wars between the Bakwena and the Bakgatla. In 1896, clear borders were drawn between these tribes. Ever since, the Bakgatla tribe is viewed as being an independent tribe.

The Dutch Reformed Church was established amongst the Bakgatla people when Pieter Brink moved to Mochudi in May 1877. The tribal wars between the Bakwena 
and the Bakgatla, as well as the fever attacks of his wife, impeded on the work, but Brink immediately started building a house, a school and a church. Although land issues between the Bakwena and the Bakgatla were not settled properly, the tribal war was ended in 1880 by the British Administration of Transvaal. In 1882, evangelist Leoke Mariri started an outpost of the mission at the Bakgatla settlement of Sikwane. In October 1885, Mme Mary Murray arrived to focus on education. Rra Segale, half-brother of Lentswe, was the first convert and later on a stalwart of the DRC mission. On 21 March 1886, Pieter Brink died at the age of 43 years, but the foundation of the then 'Nederduits Gereformeerde Sending in Bechuanaland' (Dutch Reformed Mission in Bechuanaland) was laid.

The successor of Pieter Brink was Emil Bernhard Beyer from Germany, who worked on Mochudi from October 1886 to January 1895. In 1887, nine men were baptised. One of them was Ramono, a brother of chief Lentswe. In 1889, chief Lentswe started to attend baptism classes. Lentswe decided that the tribe would build a new church building and it was handed over in 1890. From the consecration on, it was filled to capacity every Sunday. This congregation started to build two schools with their own funds. Lentswe decided to break with Traditional African Religion and sent away two of his three wives. Beyer demanded a tribal meeting in which Lentswe declared that he had turned his back on everything that is not according to Christian beliefs. ${ }^{20}$ Lentswe and his wife were baptised on 28 February 1892. Ever since, the Lord has used many missionaries and local people to build his church through the Dutch Reformed Mission in Botswana.

\section{Third wave: 1954-1976. Crossing inner boundaries}

The position of the Dutch Reformed Mission in Botswana changed in 1955 when the Tswana congregations of Saulspoort, Mabieskraal, Mochudi and Sikwane became part of the Transvaal Mission Church (Transvaalse Sendingkerk). In 1963, when the Dutch Reformed Church in Africa (DRCA/NGKA) was constituted, the church in Bechuanaland became part of the Transvaal Synod of the DRCA.

The independent Republic of Botswana came into being on 30 September 1966 with Sir Seretse Khama as its first president. ${ }^{21}$ Since independence, a closer relation developed between the white, coloured and Tswana members of the Dutch Reformed Church (still part of the RSA) and the Dutch Reformed Church in Africa (in Botswana). It is important to take note of Amanze's (2006) ${ }^{22}$ description of the Botswana context, where he states that 'the period between 1840 and 1966 was characterised by religious conflicts, which created a great deal of political, social and ecclesiastical disunity'. It is against this background that the Botswana government passed the 'Societies Bill' in 1973 with the implication that all churches had to register with government after presentation of the constitution of the church. Each denomination could only have one code number and the following question was asked: Which constitution would be handed in for registration of the Dutch Reformed Church: the one of the white 
DRC or the one of the Tswana DRCA? A Liaison Committee between the DRC and the DRCA in Botswana was constituted on 12 April 1973 in Gabarone, with representatives from all the DRC congregations with members in Botswana as well as five DRCA congregations in Botswana. This Liaison Committee was to prepare the way for a new Dutch Reformed Church in Botswana to be formed. The Liaison Committee decided to hand in the constitution of the DRCA, as it represented the larger DRC family in Botswana. With this decision, an application for registration of one DRC in Botswana was made, since the Botswana government did not allow the existence of different churches for different nationalities. ${ }^{23}$ The constitution of the Synod of the newly founded DRCB took place on 20 November 1979 with Rev. S.J. Seoke as the first moderator.

Just a month earlier, on 17 October 1979, the new Synod of the DRC in the Northern Cape had been constituted in Kimberley. The Northern Cape Synod was previously part of the Cape Synod of the DRC in SA (Sinode van Kaapland van die NGK in SA). It was at the constitution of the DRC in the Northern Cape that the (mission) work in Botswana was also transferred to the newly founded synod. ${ }^{24} \mathrm{~A}$ deed of agreement was signed between the DRCNC and the DRCB to determine the way in which these two churches would plan, administer and finance the work in Botswana in future. ${ }^{25}$

\section{Important political perspectives}

When Botswana became independent in 1966, the political situation in southern Africa was already tense; the Sharpeville massacres in South Africa happened six years previously. According to Sales (2005), ${ }^{26}$ Botswana was 'one of the 26 poorest [countries] in the world, with no ports, no industries, few communications, not even a capital city within its own boundaries'. It is important to note that the approximately 500000 residents of Botswana had no university and only a handful of secondary schools at independence. The Batswana were impoverished by their lack of any kind of skill. Skilled people were at such a premium that they were largely co-opted into government.

Since independence, a somewhat economic and social miracle happened. ${ }^{27}$ The British helped to establish the meat industry as a major exporter to the European Economic Community. Massive deposits of diamonds were discovered, which led to a new settler wave of more than 10000 technicians, advisors and administrators from all over Europe and North America. Currently, the University of Botswana as well as secondary schools are growing rapidly, not only in numbers, but also in quality. Up to date, one of the challenges in education is to find qualified Batswana to take up the educational positions.

Since 1979, the DRCNC and the DRCB have had a deed of agreement which regulates their relation. This deed of agreement contains matters like identity (the authority of the Word and the confessions), personnel matters and an agreement 
on a financial contribution from the DRCNC to the DRCB. There was no koinonia relationship between the two churches and correspondence took place whenever there was any financial need or a problem with or a need for personnel. The relationship of the Northern Cape with the DRCB was limited to the personnel who worked in the DRCB and were paid by the DRCNC, without any theological or ecumenical relationship to discern God's will. The deed of agreement relationship can be described as an agreement in which one partner gives and the other partner receives without any equality in decision-making. The two churches never gave any attention to the establishment of a place for theological education in Botswana, for the reason that the Batswana people could easily reach and study at the seminaries for the DRCA in South Africa. After Prof. W.J. van der Merwe returned from a visit to the DRC missions in different African countries, he reported on signs of a revival and an independence of the Gospel. According to Van der Watt (2003), ${ }^{28}$ Prof. Van der Merwe reported in the mission paper, Sendingblad, of May 1965 the importance of the empowering of the native members ('die afrigting van inheemse werkkragte'). These young churches should take over the leadership.

With the political situation in southern Africa during the 1970s and 80s, the border between South Africa and Botswana was 'closed' and the Batswana people were no longer allowed to study in South Africa. This would have huge theological implications for the DRCB that are still felt today. Since the late 1980s, the DRCNC Synod never took on new missionaries to work in Botswana. As personnel/ missionaries moved out of Botswana because of another calling or retirement, the positions were not filled and the money stayed in the Northern Cape Synod. The last 'missionary' from the DRCNC to leave Botswana was Rev. A.B. Cloete, who retired on 30 November 2002. From the establishment of the DRCB, well-trained, full-time Tswana ministers were involved in the leadership of the church. It remains a question whether a new generation of less equipped 'tentmaker' ministers was prepared to lead the church in 2003. A new paradigm had developed in the DRCB. Had the mission era come to an end, or not yet?

\section{Fourth wave: 1990 onwards. To the ends of the earth}

From the late 20th century, a new paradigm has started to develop. Within the new democracy in South Africa after 1994, many uncertainties dawned and in many instances, the DRC tried to avoid the realities. ${ }^{29}$ The DRC did not only lose members and money, but congregations acted more independently and started their own missions in other parts of the world than Africa. For example, through individual congregations, the DRCNC got involved with missions in Belgium in the late 1980s. Van Niekerk (1997) ${ }^{30}$ wrote the following: 'Oor die afgelope tien jaar het die inisiatief verskuif van sinodes na gemeentes, van opgeleide sendelinge na lidmate, van ' $n$ plaaslike en Afrika-fokus na 'n globale visie.' (During the past ten years, the mission initiative moved from synods to congregations, from trained missionaries to 
members, from a local and Africa focus to a global vision.) The DRCNC was bound to the DRCB by their deed of agreement.

Describing this relationship from a DRCB perspective, Stoltz $(2001)^{31}$ noted that at the 1997 Synod of the DRCB, the local leaders had an intense wish to localise. The struggle to localise and gain a new identity became clear when the work permit of the 2003-2004 moderator, Rev. Gonese, a Zimbabwean citizen, was terminated. On 18 February 2000, the DRCNC received a document from the DRCB, called 'Vision 2010', which mirrors this wish to localise. Amongst very important and beautiful statements regarding poverty and HIV/AIDS, the unattended wish to be recognised as an equal and independent partner was stated between the lines. In the introduction, it is stated that 'the strategies proposed here are starting points for a new direction for the DRCB that builds upon our strengths and upon the common desires of our people'. ${ }^{32}$ Talking about the 'National Principle', the document stated that 'the principle for the church will be "Botho", which refers to one of the tenets of African culture'. ${ }^{33}$ Regarding the governance of the DRCB, it is stated that "the church in future will be community-orientated democracy, with strong decentralised institution...The inner democratic process will be continually deepened and enriched in accordance with the general evolution of the society and wishes of congregations' ${ }^{34}$ Evaluating this document, it is obvious that there is a clear lack of the Reformed principles, which can be seen as a lack of (Reformed) theological education. Stoltz $(2001)^{35}$ makes a noteworthy comment when he states that within the African context, attention must be given to a faith experience rather than a religious experience.

At the request of the DRCB, the DRCNC made a contribution to the salary of an administrator in the person of Mr ED Mooketsi, who was appointed on 1 July $2000 .{ }^{36}$ On 26 June $2001 \mathrm{Mr}$ Mooketsi wrote a letter to the office of the DRCNC in which the following was stated: 'We are of the view that DRCB and DRCNC should increase the level of contact and exchange of ideas for the growth of both churches.' It became clear that the deed of agreement between the DRCB and the DRCNC had become outdated and that there was a need for a new relationship.

Serious attention was given by the DRCNC task team to the following questions: Have we come to the end of our involvement with the DRCB? Has the DRC reached its goal to plant a self-governing, self-propagating and self-supporting church? Was it not time for terminus ad quem of our involvement in Botswana? ${ }^{37}$ It was during this time that the DRCB task team of the DRCNC re-evaluated its involvement. The following factors were considered: on a practical level, with no 'missionaries' from the DRCNC, there were no full-time ministers in the DRCB ${ }^{38}$ which was still a big concern, although this was the only way in which the DRCB could be self-supporting at the time. The level of theologically trained ministers ${ }^{39}$ who were 'tentmakers' brought big challenges to the ministry and self-governance of the church. The historical link and Reformed theology, as well as the process of uniting the Dutch Reformed Churches in South Africa and the opening up to work in Africa again, encouraged the DRCNC to stay involved. The DRCNC task team realised the 
problem of an independent church that was still theologically dependent ${ }^{40}$ and was convinced that the DRCNC still had an important contribution to make to the DRCB. The DRCNC task team was also convinced that they needed the DRCB to help the Northern Cape to understand the needs of Africa and thus their own context, as well as how to have an efficient ministry in Northern Cape rural areas. Although the relationship should continue, it could no longer be a 'deed of agreement'. It needed to be a partnership relationship in which they were involved, because they needed each other to be better participants in the missio Dei.

Kritzinger (2011) indicates that the situation in which the DRC found itself was the result of an insufficient mission policy, as the sustainability of the work that had been started was never questioned. For the DRCNC, it was clear that a deed of agreement relationship was outdated. 'Unknowingly', the Liaison Committee engaged in getting involved in projects (with a beginning and an end) that were initiated by the different churches to address specific needs. In addressing the needs together, going through times of trust and distrust, a more mature, vulnerable and koinonia relationship developed. The DRCNC realised that they could no longer prescribe or demand, but could only give advice if they were asked to do so; they also realised that they didn't have all the answers. The DRCNC realised that they had to engage in prophetic dialogue (described by Bevans and Schroeder 2011 ${ }^{41}$ ) in the authors' images of mission. ${ }^{42}$ The DRCB realised that as a partner and an initiator in some projects, they could not only demand, but also had to take on certain responsibilities and be accountable to produce fruits from their own garden. It was in this struggle of redefining roles and responsibilities that they became vulnerable before each other and realised their inter-dependence. Without knowing or constructively working towards it, they were developing a partnership agreement in which partners are equal and powerless. It was only in 2007 that an official decision was taken on the matter. To date, the partnership document is viewed as a working document in progress. 'The purpose of the Partnership agreement is to work towards co-operation and respect and enhance the ministry of witness and evangelism, of caring and serving, and of community development in the DRCB with the DRCNC' ${ }^{43}$ It was only when Rev. Radikgomo became the moderator of the DRCB and attended a workshop on partnerships that was organised in 2009 by the General Synod of the DRC for all the DRC churches in Africa that the partnership between the DRCNC and DRCB grew. In their co-operation to enhance the ministry, the following projects were identified.

- Relations

Both churches realised that the relationship could not only exist within the Liaison Committee. Some of the Afrikaans-speaking members of the DRCB were also unhappy with the structural functioning of the church, since the official languages were English and Setswana and they longed for a ministry in Afrikaans. On the other hand, the DRCB was unhappy with DRC ministers coming from South Africa, conducting services and even sacraments without the consent of the local church 
council. The DRCNC had conversations with the DRC Synod of Northern Transvaal as well as with the general secretary of the General Synod of the DRC with some positive outcomes in this regard.

There were also some efforts to get congregations and presbyteries involved in building relationships. The DRCNC Synod of 2006 took a decision in which the presbyteries of the DRCNC were linked to specific congregations in the DRCB. Some presbyteries, like Griekwastad, had several outreaches to the DRCB Lobatse congregation and contributed through evangelism, research on poverty and also helped to build the church at Sethlareng. Lobatse congregation visited DRCNC Danielskuil congregation and helped them with an evangelism project.

The presbytery of Warrenton is also involved in the Kgalagadi congregation. After many years of outreach to Tsabong, where they helped with the church building, they realised that there was no minister to conduct the services in the new building. Rev. T.C. du Toit, the initiator of the outreaches, gave up his position as minister of Hartswater congregation and took on 'faith ministry' 44 in order to serve the Kgalagadi congregation. Hartswater congregation is still very involved in the Kgalagadi ministry.

\section{- Town house project}

In a letter from Mr Mooketsi to the DRCNC (written on 26 June 2001) we find an indication of what would later be known as the 'town house project'. It reads: 'We are seriously considering...to enter property business to provide accommodation and office space to the growing economy in Mochudi. The demand for office space and accommodation is very big business.' At the Liaison Committee meeting in 2003, the following was reported on the town hose project:

The DRCB requested an amount of P300 000-00 from the DRCNC, and will loan P310 000.00 from the bank. If the DRCNC will give them the P300 000.00, the DRCB proposed the phasing out first of the administrator's salary, and when the project is in place the grand sum of R110 000-00 per year will be phased out. The phasing out period will be 5-10 years.

The meeting agreed to go back to their different synods in October and November, and 'if the Synods approve, there will be a follow-up meeting to work out the details'. The DRCNC Synod of $2003^{45}$ approved the proposal in principle, but with the following condition: '...sonder dat die verhouding tussen die NG Kerk Noord Kaapland en DRCB of die bediening in die DRCB sal skade ly' (the relationship between the DRCNC and the DRCB or the ministry within the DRCB must not be influenced negatively). This was approved without any negative financial implication for the DRCNC.

After the DRCB could not secure the P310 000.00 loan from the bank, the DRCNC Synod decided in 2005 to give the amount of P652 000.00 to the DRCB to build one town house. ${ }^{46}$ The town house was completed in 2008 when all formal 
allowances to the DRCB were stopped. The income from the town house was to contribute to the self-sustainment of the DRCB. Theological education Without any personnel of the DRCNC in the DRCB, the relationship between the two churches also changed. With the fast growing educational situation in Botswana after independence, the DRCB suddenly found itself in the dawn of the new century with more educated members who asked for a more educational ministry. DRCB ministers realised that their certificate in theological training needed to be enhanced. The DRCB ministers also became aware of their theological vulnerability when they engaged in ecumenical discussion with other denominations and churches. It is from this background that the request came to the DRCNC to help with theological training. The DRCNC Synod requested the DRCB task team to give attention to theological education in the DRCB.

The DRCNC and DRCB agreed that only accredited courses would be presented. The DRCB started with continuous education for its ministers; a short course in 'Building up the local church' from Contextual Ministry at the University of Pretoria was presented in 2004 to ministers of the DRCB in Mochudi. At the same time, three ministers from the DRCNC started with the Nehemia training for 13 church council members in the Kgalagadi. ${ }^{47}$ Although all agreed that it was very informative, practical implications constrained these efforts. A request was received from the DRCB to the DRCNC to get involved in the training at Kgolagano College ${ }^{48}$ where the ministers of the DRCB were trained. Kgolagano College was only accredited to teach at certificate level and requested the DRCNC to help them teach at degree level. At this time, there was no tuition for a theological degree in Botswana; only a degree in Religious Studies was presented at the University of Botswana. It was against this background that the DRCB task team decided to not only attend to the needs of the DRCB, but also to the church in Botswana, without forsaking the DRCB.

In 2007, an official agreement was reached between Kgolagano and the University of Pretoria to present short courses at Kgolagano. The understanding was that ministers from the DRCB would attend these courses as part of their continuous education. The DRCNC also received an official request from Kgolagano College to help with an academic who would be able to lecture degree courses. The DRCNC Synod of 13-16 October 2008 took the decision to go into partnership with the Centre for Contextual Ministry at UP and to sponsor the salary of an academic to teach at Kgolagano for two years. Since it was an interim position that was only granted for two years, no suitable person could be found. The Centre for Contextual Ministry negotiated with the Dutch Reformed congregation of Daniëlskuil and it was only in 2010, when the post was changed to a 50 per cent post, that it was filled. The DRCNC agreed to negotiate with academic institutions in South Africa to present a BTh degree at Kgolagano. Since none of the DRC's theological faculties were able to help, the Theological Faculty of the North-West University (NWU) agreed to present their degree at Kgolagano. Since January 2011, the BTh degree of the NWU is presented at Kgolagano and the first group of 13 students will receive their BTh 
degrees at a graduation ceremony in 2015 at the Mafikeng Campus of the NWU. One of these students is currently a minister from the DRCB who, together with six other students, has already enrolled for the BA Honours in Theology. A previous registrar and Principal of Kgolagano, Rupert Hambira, also obtained his Master's degree in Missiology cum laude in 2014. With the collaboration of the NWU, Kgolagano College was able to register their own BTh degree in 2014.

Although there are some concerns about the management of the projects, it can be stated boldly that the Liaison Committee has reached its goal to build a partnership that contributes to the self-sustainment and self-expansion of the DRCB.

\section{Where are we?}

It is a fact that the DRCNC had never properly planned the relationship with the DRCB; in fact, the newly found Synod of the DRCNC inherited a mission in 1979 that was older than 100 years. Viewed in a different light, it could be said that the new DRCNC inherited a relationship with a newly found church (DRCB), not even one year old, who, because of a socio-political development, is self-governing, but not yet self-supporting or self-expanding. It is true that in both South Africa and Botswana the socio-economic and political situation has sometimes forced the churches to take decisions that they might not have taken had the situation been different. Evaluating these decisions theologically, ${ }^{49}$ the fact that we are privileged to participate in the missio Dei and are not busy with our own missions, fills us with hope. The question that remains is the following: What must happen with the relationship in future?

Fuller $(1981)^{50}$ describes the developing relationship in mission in four phases: first, the pioneer phase, in which the missionary is very important; second, the parent phase, with the focus on teaching; third, the partner phase, in which the church takes responsibility for its own matters within the safety of a supportive relationship; and fourth, the participant phase, in which participation is on invitation only. It is clear that phase one is finished. Currently, we find ourselves fluctuating within the other three phases; we are in phase two, because, although we have started with the theological education of ministers, a lot still has to be done to empower church councils and members of the congregations to use their gifts for the benefit of all (1 Cor. 12:7). ${ }^{51}$ Regarding the self-support of the DRCB, we find ourselves within phase three, although we no longer support them financially. This is very important for the development of the church ${ }^{52}$ but just as important is the fact that we are still in a supportive relationship regarding financial and general management. In 2014, we had the privilege to experience phase four when the DRCNC was invited to participate in the Synod Meeting of the DRCB in Mochudi from 3-6 December 2014.

As the two churches stand before each other and the world, it is as powerless partners, participating in the missio Dei by the grace of God, like one beggar telling another where to find bread. 


\section{ENDNOTES}

1. Van der Watt. 2003. 'Die sendingpraktyk van die NG Kerk: Enkele tendense vanaf 1952 tot met die eeuwenteling,' Verbum et Ecllesia 24(1): 213-231.

2. Kritzinger, 2011. 'Die einde van sending: Fases in die sendingbedryf,' Acta Theologia 2: 11-134.

3. Dr J.J. Knoetze was chairperson and member of the DRCB task team of the DRCNC from 2002-2014. He was also chairperson of the Service And Witness Committee from 2007-2011; after a short break, he was re-elected as vice-chairperson in 2014.

4. Kritzinger, Meiring and Saayman. 1994. On being witnesses. Halfway House: Orion Publishers, p. 1.

5. Cf. Crafford. 1982. Aan God die dank. Deel 1. Goodwood:, Kaap: NG Kerkboekhandel Transvaal; and Cronje, 1981. Aan God die dank. Deel 2. Pretoria: NG Kerkboekhandel Transvaal.

6. Kritzinger et al. 1994. On being witnesses. Halfway House: Orion Publishers, p. 8.

7. General Synod of the Dutch Reformed Church in South Africa. Minutes: Agenda and acts of the synod session, Pretoria, 13-19 October 2002, p. 584.

8. Cf. General Synod of the Dutch Reformed Church in South Africa. Minutes (2002): 566; and W.C. van der Merwe. 2014. 'Met woord én daad in diens van God:.Die diakonaat van die NG Kerk in post-apartheid Suid-Afrika.' PhD, University of Stellenbosch, p. 115.

9. Bosch. 2012. Transforming mission: Paradigm shifts in theology of mission. 2nd edition. New York: Orbis Books, p. 188.

10. Working with this definition of a paradigm, it is a synonym for terminology used later in this article, like, 'waves' (Saayman), or 'phases' (Fuller).

11. Saayman. 2007. Being missionary, being human: An overview of Dutch Reformed Mission. Pietermaritzburg: Cluster Publications, p. 1.

12. For a discussion on the meaning and the significance of the term 'waves', see Saayman (2007, 9-13).

13. Bosch $(2012,191)$.

14. Bosch $(2012,190)$.

15. Martin (1987) in Bosch $(2012,192)$.

16. Sales. 2005. A case in point: The Botswana theological training programme. Gaborone: Kgolagano Press, p. 4.

17. Sales $(2005,9)$.

18. Crafford. 1982. Aan God die dank. Deel 1. Goodwood: NG Kerkboekhandel Transvaal, p. 83.

19. Sales $(2005,3)$.

20. Crafford $(1982,86)$.

21. Crafford $(1982,281)$.

22. Amanze. 2006. Ecumenism in Botswana: The story of the Botswana Christian Council. Gaborone: Pula Press, p. 1. 
23. Crafford $(1982,296)$.

24. Crafford $(1982,287)$.

25. Crafford $(1982,297)$.

26. Sales $(2005,5)$.

27. Sales $(2005,6)$.

28. Van der Watt $(2003,217)$.

29. Van der Watt $(2003,225)$.

30. Van Niekerk. 1977. 'Einde of begin vir die NG Sending?' NGTT, 38(4): 414.

31. Stoltz. 2001. "n Geïnkultureerde bedieningsmodel vir die gemeentes van die Dutch Reformed Church in Botswana.' PhD, Bloemfontein: University of the Free State.

32. Dutch Reformed Church in Botswana (DRCB). 'Vision 2010: A vision steadfastly rooted in faith.' Mochudi: Synod office, 2000, 1.

33. DRCB. 'Vision 2010,' p. 2.

34. DRCB. 'Vision 2010,' p. 3.

35. Stoltz $(2001,10)$.

36. Commission for Ecumenical liaison of the Dutch Reformed Church in the Northern Cape and the Executive Council of the Dutch Reformed Church in Botswana. Minutes: Meeting held in the synodical office, Kimberley, 9 November 2000.

37. Cf. Kritzinger $(2011,112)$.

38. Only two white congregations, Lobatse and Ghanzi, had full-time ministers at that time. Currently, Lobatse has no minister. Ghanzi did not have good relations with the DRCB at that stage and chose to be only an observer at the Synod.

39. Up to 2014, there was only one minister with a theological degree. The average of the theological training of ministers was a one-year certificate.

40. Cf. Kritzinger $(2011,118)$.

41. Bevans and Schroeder. 2011. Prophetic dialogue: Reflections on Christian mission today. New York: Orbis Books.

42. Bevans and Schroeder (2011, 31-34) use the powerful images of, inter alia, a treasure hunter, guest, stranger, and entering into someone else's garden.

43. Minutes Liaison Committee, 2007.

44. 'Faith ministry' refers to the fact that he has no fixed income and is supported through the donations of benefactors

45. Synod of the Dutch Reformed Church in the Northern Cape. Minutes: Agenda and acts of the synod session, 2003: 238, point 3.2.3, Kimberley, October 2003..

46. Synod of the Dutch Reformed Church in the Northern Cape. Minutes: Agenda and acts of the synod session, 2005: 248, point 3, Kimberley, 10-13 October 2005.

47. Task team of the Dutch Reformed Church in Botswana. Report to the Synod of the Dutch Reformed Church in the Northern Cape, Kimberley, 2005.

48. Kgolagano College is an interdenominational Theological College that was started by the

49. Hendriks $(2007,21)$ describes theology as one discipline which is missionary by its very nature. 
50. Fuller. 1981. Mission-church dynamics. Pasadena: William Carey Library.

51. The important relationship between theology and congregations is essential for the further development of the relationship between the DRCB and the DRC. However, it is not in the scope of this article to discuss it. See Keifert (2009) in this regard.

52. Cf. Kritzinger $(2011,129-130)$.

\section{LIST OF REFERENCES}

Amanze, J.N. 2006. Ecumenism in Botswana: The story of the Botswana Christian Council. Gaborone: Pula Press.

Bevans, S.B. and R.P. Schroeder. 2011. Prophetic dialogue: Reflections on Christian mission today. New York: Orbis Books.

Bosch, D.J. 2012. Transforming mission: Paradigm shifts in theology of mission. 2nd edition. New York: Orbis Books.

Commission for ecumenical liaison of the Dutch Reformed Church in the Northern Cape and the executive council of the Dutch Reformed Church in Botswana. Minutes: Meeting held in the synodical office, Kimberley, 9 November 2000.

Crafford, D. 1982. Aan God die dank. Deel 1. Goodwood: NG Kerkboekhandel Transvaal.

Cronje, J.M. 1981. Aan God die dank. Deel 2. Pretoria: NG Kerkboekhandel Transvaal.

Dutch Reformed Church in Botswana (DRCB). 2000. Vision 2010: A vision steadfastly rooted in faith. Mochudi: Synod Office.

Fuller, W.H. 1981. Mission-church dynamics. Pasadena: William Carey Library.

General Synod of the Dutch Reformed Church in South Africa. Minutes: Agenda and acts of the synod session, Pretoria, 13-19 October 2002.

Hendriks, H.J. 2007. Studying congregations in Africa. 3rd edition. Cape Town: Lux Verbi.

Keifert, P. 2009. Testing the spirits: How theology informs the study of congregations. Grand Rapids: Eerdmans.

Kritzinger, J.J. 2011. 'Die einde van sending: Fases in die sendingbedryf.' Acta Theologia 2: 11134.

Kritzinger, J.J., P.G.J. Meiring and W.A. Saayman. 1994. On being witnesses. Halfway House: Orion Publishers.

Liaison Committee of the Dutch Reformed Church in Botswana and the Dutch Reformed Church in the Northern Cape. Minutes. Mochudi/Motswedi, 1 November 2007.

Mooketsi, E.D. 2001. Letter from the DRCB to the DRCNC: The relationship between the DRCB and the DRCNC. Synod Office of the DRCB, Mochudi.

Saayman, W. 2007. Being missionary, being human: An overview of Dutch Reformed mission. Pietermaritzburg: Cluster Publications.

Sales, R. 2005. A case in point: The Botswana theological training programme. Gaborone: Kgolagano Press.

Service and Witness Committee of the Dutch Reformed Church in the Northern Cape. Minutes. Kimberley, 26 May 2005. 
Shenk, W.R. 1981. 'Rufus Anderson and Henry Venn: A special relationship?' International Bulletin of Missionary Research 5(4): 168-172.

Stoltz, P.S. 2001. " $n$ Geïnkultureerde bedieningsmodel vir die gemeentes van die Dutch Reformed Church in Botswana', PhD. Bloemfontein: University of the Free State.

Synod of the Dutch Reformed Church in the Northern Cape. Minutes: Agenda and acts of the synod session, Kimberley, October 2003.

Synod of the Dutch Reformed Church in the Northern Cape. Minutes: Agenda and acts of the synod session, Kimberley, 10-13 October 2005.

Task team for the Dutch Reformed Church in Botswana. Report to the Synod of the Dutch Reformed Church in the Northern Cape. Kimberley, 2005.

Van der Merwe, W.C. 2014. 'Met woord én daad in diens van God: Die diakonaat van die NG Kerk in post-apartheid Suid-Afrika', $\mathrm{PhD}$, University of Stellenbosch.

Van der Watt, G. 2003. 'Die sendingpraktyk van die NG Kerk: Enkele tendense vanaf 1952 tot met die eeuwenteling. 'Verbum et Ecllessia 24(1): 213-231.

Van Niekerk, A.S.1997. 'Einde of begin vir die NG Sending?' NGTT 38(4): 408-416. 